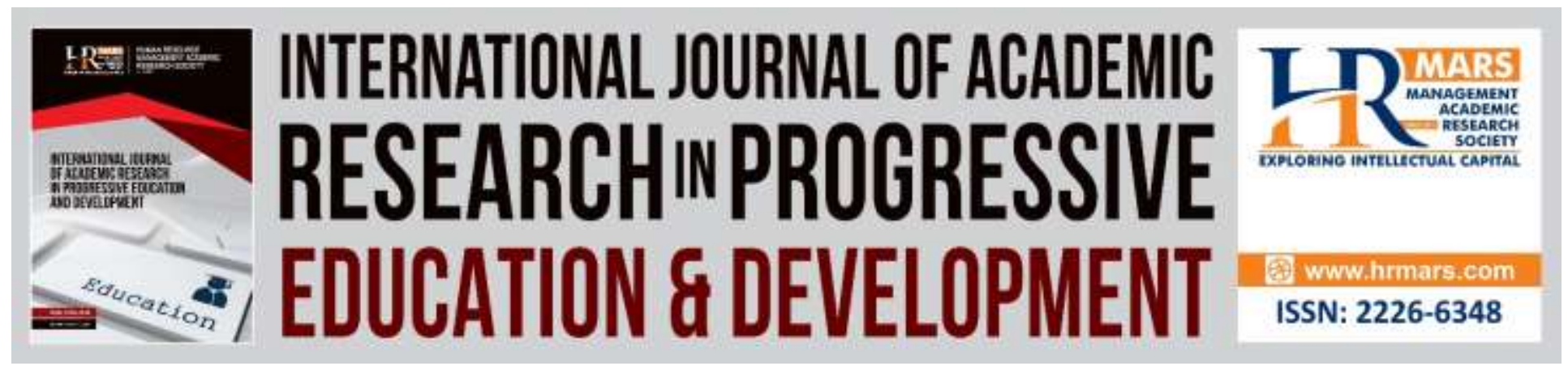

\title{
E-Mufradat: A Digital Game Application for Learning Arabic Vocabulary among Non-native Arabic Speakers
}

Mohammad Taufiq Abdul Ghani, Mahizer Hamzah, Taj Rijal Muhamad Romli, Mohammed Abdulaziz Mohammed Ahmed Eltigani, Wan Ab Aziz Wan Daud

To Link this Article: http://dx.doi.org/10.6007/IJARPED/v8-i3/6261

DOI: 10.6007/IJARPED/v8-i3/6261

Received: 10 June 2019, Revised: 27 June 2019, Accepted: 12 July 2019

Published Online: 29 August 2019

In-Text Citation: (Ghani, Hamzah, Romli, Eltigani, \& Daud, 2019)

To Cite this Article: Ghani, M. T. A., Hamzah, M., Romli, T. R. M., Eltigani, M. A. M. A., \& Daud, W. A. A. W. (2019). E-Mufradat: A Digital Game Application for Learning Arabic Vocabulary among Non-native Arabic Speakers. International Journal of Academic Research in Progressive Education and Development, 8(3), 58-69.

\section{Copyright: (C) 2019 The Author(s)}

Published by Human Resource Management Academic Research Society (www.hrmars.com)

This article is published under the Creative Commons Attribution (CC BY 4.0) license. Anyone may reproduce, distribute, translate and create derivative works of this article (for both commercial and non-commercial purposes), subject to full attribution to the original publication and authors. The full terms of this license may be seen at: http://creativecommons.org/licences/by/4.0/legalcode

Vol. 8(3) 2019, Pg. 58 - 69

Full Terms \& Conditions of access and use can be found at http://hrmars.com/index.php/pages/detail/publication-ethics 


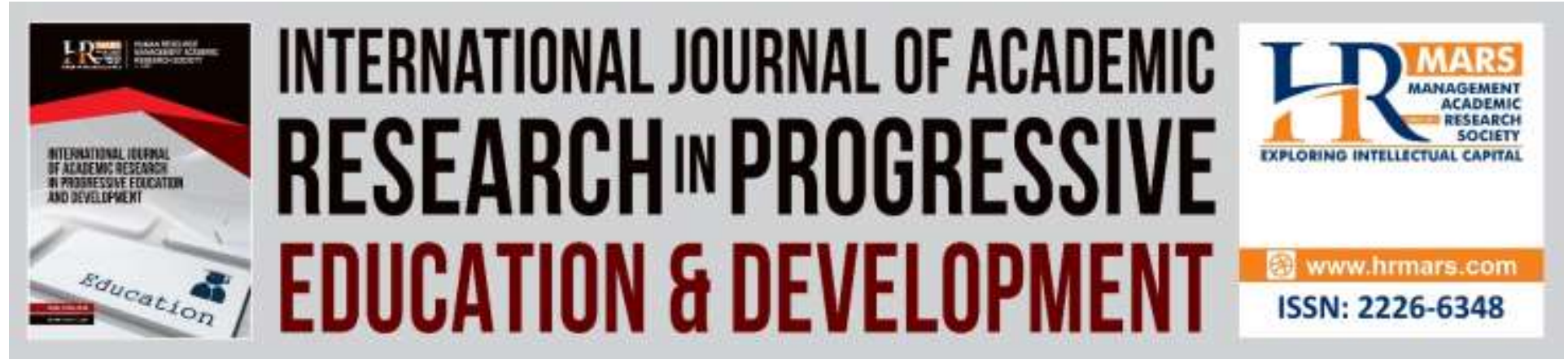

\title{
E-Mufradat: A Digital Game Application for Learning Arabic Vocabulary among Non-native Arabic Speakers
}

\section{Mohammad Taufiq Abdul Ghani ${ }^{1}$, Mahizer Hamzah², Taj Rijal Muhamad Romli3 ${ }^{3}$, Mohammed Abdulaziz Mohammed Ahmed Eltigani ${ }^{4}$, Wan Ab Aziz Wan Daud ${ }^{5}$ \\ 1,3,4 Faculty of Languages and Communication, Universiti Pendidikan Sultan Idris, Perak,} Malaysia, ${ }^{2}$ Faculty of Human Development, Universiti Pendidikan Sultan Idris, Perak, Malaysia, ${ }^{5}$ Centre for Language Studies and Generic Development, Universiti Malaysia Kelantan, Kelantan, Malaysia

\begin{abstract}
A good educational digital game should be error free and engaging to ensure it can increase students' learning motivation. While there is an abundant of educational digital games available in the market, many seem to not fulfil players' need and some contain technical or content errors, which will defy their purpose as education games. Thus, this study aims to validate eMufradat which is an educational digital-game application for learning Arabic vocabulary. This study is a qualitative study and the data were collected through semi-structured interviews with nine experts in instructional design and technology and Arabic as a second language. The subject matter experts were selected purposively from various universities in Malaysia. The finding indicates that e-Mufradat is aligned with multimedia learning theory and embedded digital game-based learning principles.
\end{abstract}

Keywords: E-Mufradat, Educational Digital Game, Digital Game-Based Learning, Multimedia Learning, Game Application.

\section{Introduction}

A language's vocabulary represents all words in the language and its knowledge is imperative in the formation of the lexical system. In the context of language use vocabulary is known as lexicon which comprises of the plethora of basic words that could be used in different situations, and according to (Nathesan, 2011). Another important concept in language learning is vocabulary size which refers to volume of words known by an individual (Zaini \& Abd Rahman, 2017). It is argued that most words have the same value and priority for native speakers, however, in the 
context of learning a second language, there are only a handful of words that are frequently used and have higher values compared to other words (MCKeown \& Beck, 2004; Nation, 2001). Furthermore, it is argued that a second language speaker is required to know at least 2000 high frequency words to understand $80 \%$ of the text in the second language. This reflects the need for second language learners to acquire a realistic amount of vocabulary to understand text or communicate in the target language, particularly in the context of higher learning (Schmitt, 2000).

Having a rich vocabulary is important for second language speakers. This because the use of accurate words will bring understanding even when the words are poorly pronounced and incorrectly inflected (Tight, 2010). Bauman and Kame'enui (2003) highlighted that a large vocabulary will affect one's language skills. Previous studies reported rich vocabulary can be obtained through specific and special strategies to learn vocabulary such as using pictures and clue cards. Furthermore, in some cases, students use contextual clues or guesses to understand words that they do not know (Nacera, 2010).

Digital game-based learning is one of the educational approaches that has positive impact on students (Hamizul \& Rahimi, 2015) and it could potentially help students to expand their vocabulary size in an interactive way. Previous studies have suggested the use of game-based learning to increase students' motivation to learn vocabulary (Paiva et. al., 2016; Hussain et. al, 2014; Sung \& Hwang, 2013; Hwang et. al., 2012; Yien et, al., 2011; Lee \& Hammer, 2011). In this light, teachers can adopt educational games across different learning levels for students with different level of proficiency, including in tertiary level. Papastergiou (2009) reported that through educational game, students can improve knowledge of the subject matter and at the same time, gain enjoyment. Consequently, this will increase their engagement and motivation for learning.

There are many Arabic digital games sold in market do not meet student's needs, learning setting and facilities (Nurkhamimi \& Sabri, 2015). This is because the game development process does not follow the theories and principles, and some of the products do not go through validation process from the experts. Therefore, these games are failed to sustain student's engagement and motivation in learning process. In addition, some of the products also contain technical or content errors, which will defy their purpose as education games. In line with the above discussion, this study explores the validity of the e-Mufradat digital game application prototype through a validation process involving subject matter experts. The prototype was analysed to ensure the quality of the product and effectiveness of its design before it is used in classrooms.

\section{Background of Study}

Vocabulary acquisition is an important component in building language proficiency. Vocabulary size has a significant relationship with language skills and it is stipulated that a larger vocabulary size will help students to become more proficient in other language skills (Razif \& Zaki, 2017). As vocabulary is one of the main determiners of language profiency, it could be argued that the lack of vocabulary might make students reluctant to practice language skills (Zhang \& Li, 2011; Ismail et al., 2016). In order to enrich students' vocabulary, an innovative learning strategy is needed and the researchers are proposed a digital game as tool in vocabulary learning strategy. Due to 
its importance, vocabulary acquisition has become one of the core focus of language learning and has garnered the interest of researchers topics since the last two decades (Gu, 2010). Subsequently, researchers have came out with various approaches and strategies for effective vocabulary the and learning.

In the context of Arabic learners in Malaysia, studies have found that most Malaysian students only have limited vocabulary and they are not able to communicate well in Arabic (Hussin, 2002; Hashim, 2010; Razak et al., 2016; Zailani et al., 2016; Ishak, \& Arifin, 2016). This might be due to low motivation to learn the language as they do not enjoy learning Arabic. This reflects the need to improve vocabulary acquisition among Malaysian students.

One of the reasons for the low Arabic proficiency among learners is the lack of motivation to learn the language. The present Arabic language teaching and learning practice is predominantly teacher-centred where teachers largely use chalk and talk to deliver their lessons (Rosni, 2009). It was also reported that at the tertiary level, lecturers use translation and memorisation (Rosni, 2009) which do not they find it hard to memorise the vocabulary. As a result, most students learn Arabic just to pass the examination and as argued by (Janudin, 2017), the exam oriented system often give students limited opportunity to master the language

In this regard, teachers should facilitate active learning through using different approaches, including incorporating electronic materials available around the learners (Rosni, 2017). Digital game is an effective tool with good potential to help learners, particularly those who are digital natives. It has been recognised as a learning tool that could motivate students to actively participate in the teaching and learning activities (Alessi \&Trollip, 1984; Baid \& Lambert, 2010; Kirikkaya et al., 2010; Sahrir, 2011; Hamzul \& Nik Mohd Rahimi, 2015). The use digital games can improve students' engagement in the learning process and increase their knowledge. Furthermore, advocates of digital games have posited that they could help develop soft skills such as leadership and decision-making (Paiva et al., 2016; Sung \& Hwang, 2013; Hwang, Wu, \& Chen, 2012; Najdi \& Sheikh, 2012; Lee \& Hammer, 2011; Yien, Hung, Hwang, \& Lin, 2011; Papastergiou, 2009).

In order to ensure the quality of the digital game to be used in teaching and learning, one of the crucial process need to be employed which is expert validation. For educational game, the content should be validated by the subject matter experts, so that it become suitable for students and meet their expectation. Besides, the content also should be alligned with learning objectives and learning outcomes. In addition, the technical issues also should be validated to avoid the errors in in the digital game. The principles and theories also need to be inctegrated into the digital game to assist the students in learning Arabic language in an interactive way.

\section{Digital Game-based Learning}

Digital game-based learning is a form of gaming which is normally designed for other purposes like for entertainment. Conventional game-based learning compises of different forms of strategy-based entertainment board games. As shown below, digital game-based learning shares many features with other instructional media (Breer \& Bente, 2010). Studies have reported that digital game-based learning could enhance teaching and learning and the use of digital games in learning has gauged the interest of many researchers. Digital-based learning has defined in various ways; Prensky (2001) digital game-based learning is a novel electronic learning (e- 


\section{INTERNATIONAL JOURNAL OF ACADEMIC RESEARCH IN PROGRESSIVE EDUCATION AND}

DEVELOPMENT

Vol. 8, No. 3, 2019, E-ISSN: $2226-6348$ @ 2019 HRMARS

learning) model while Kim, Park, \& Baek, (2009) defined is at as a learning strategy to ensure particular learning objectives are achieved through game play. Salen and Zimmerman (2004) described that educational games require players use the prescribed rules to solve simulated conflict in order to achieve quantifiable learning outcomes. Similarly, Juul (2003) elaborated that digital games is a rule-based system with quantifiable outcomes with different values where players will attempt to achieve the desirable outcomes. In this light, in some games, the outcomes of each level might be could optional and negotiable. Subsequently, players will be motivated to work towards achieving the goal.

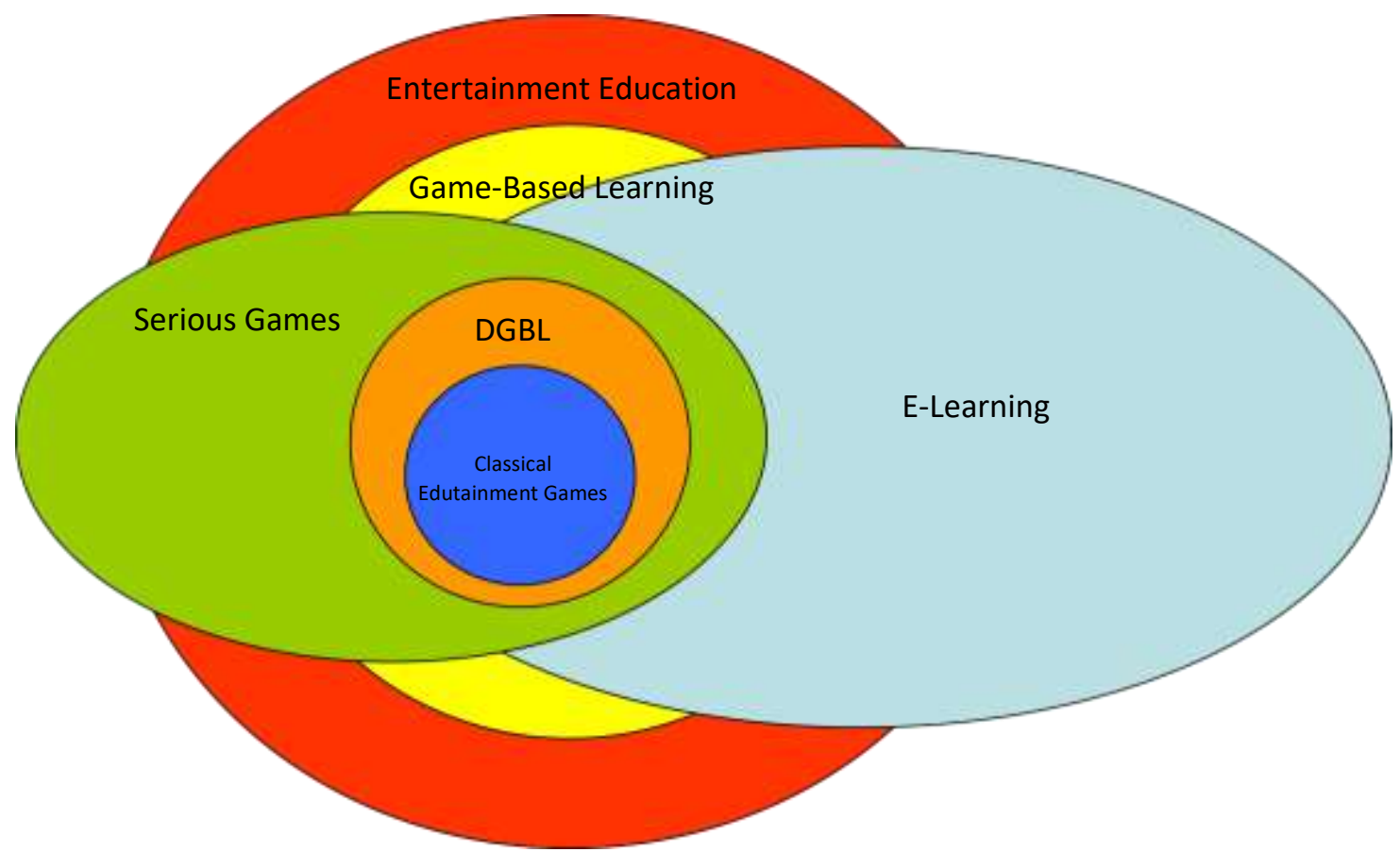

Figure 1 Overview of Digital Game-based Learning and Similar Instructional Media Concept

Digital game-based learning combines entertainment and education to serve educational purpose. This concept is known as edutainment. Digital game-based learning is a form of game play aimed to help teachers achieve learning outcomes. It can also be subcategorised under elearning as the materials are delivered to remote learners electronically via a computer network (Zhang et. al, 2004). In this study, digital game-based learning refers to the adoption of digital games to bring an element of fun and entertainment to achieve an educational outcome (Prensky, 2001). Thus, the digital game used needs to be fun, entertaining and engaging and also, has an educational benefit (Belloti et al., 2013). Studies have found that employing digital-games in the traditional classroom environment could increase students' engagement and encourage problem solving.

\section{Methodology}

This study is a qualitative study and the main data collection and analysis within design and development research methodology (Richey \& Klein, 2007). The rationale for utilizing methods and approaches of design and development research was to emphasis on both research and 
practice when producing a valid, practical and effective mobile digital game application prototype (Iverson, 2005; Nurkhamimi \& Muhammad Sabri, 2015).

According to Creswell (2018), in qualitative interviews the researchers conduct face-toface interviews with participants, telephone interviews, or engages in a focus group interviews with six to eight interviewees in each group. This interviews involve unstructured and generally open-ended questions that are few in number and intended to elicit views and opinions from the participants. Therefore, this study employs a semi-structured interviews consisting open-ended questions without optional response for interviewees.

The data were collected during semi-structured interviews with nine subject matter experts in teaching Arabic as a second language, and instructional design and technology. These experts work in various universities and were chosen purposively. The experts were asked to give response to the questions after reviewing the e-Mufradat application. This information is important to sustain validity, quality, practicality and effectiveness of e-Mufradat as learning tool among non-native learners. The results were analysed qualitatively and presented into several themes.

\section{Results and Findings}

A total of nine experts in instructional design and technology and Arabic as a second language comprising different universities were participated in this study. The results of validation process among experts were reported in two sections; expert's demographic background and instructional design validation. The results are as follow:

Section A: Experts' Background

\begin{tabular}{|c|c|c|c|}
\hline Item & Sub-Item & Frequency & Percentage (\%) \\
\hline \multirow[t]{5}{*}{ Designation } & Lecturer & 0 & 0 \\
\hline & Senior Lecturer & 1 & 11 \\
\hline & Assoc. Professor & 7 & 78 \\
\hline & Professor & 1 & 11 \\
\hline & Total & 9 & 100 \\
\hline \multirow[t]{6}{*}{ Academic Qualification } & Diploma & 0 & 0 \\
\hline & Bachelor & 0 & 0 \\
\hline & Master & 0 & 0 \\
\hline & $\mathrm{PhD}$ & 9 & 100 \\
\hline & Others (eg: EdD) & 0 & 0 \\
\hline & Total & 9 & 100 \\
\hline \multirow[t]{5}{*}{ Teaching Experience } & 5 years & 0 & 0 \\
\hline & 10 years & 0 & 0 \\
\hline & 15 years & 1 & 11 \\
\hline & 20 years & 8 & 89 \\
\hline & Total & 9 & 100 \\
\hline \multirow[t]{3}{*}{ Specialization } & Instructional Design \& Technology & 5 & 56 \\
\hline & Arabic as a Second Language & 4 & 44 \\
\hline & Total & 9 & 100 \\
\hline
\end{tabular}

Table 0-1 Expert's Demographic Background 


\section{INTERNATIONAL JOURNAL OF ACADEMIC RESEARCH IN PROGRESSIVE EDUCATION AND}

DEVELOPMENT

Vol. 8, No. 3, 2019, E-ISSN: $2226-6348$ @ 2019 HRMARS

The table above illustrates the background of experts in validation process of e-Mufradat prototype. All of them are PhD holders and majority of them have more than 20 years of teaching experience. The results also show that five of them are specialize in instructional technology and the remaining of four are specialize in Arabic language.

\section{Section B: Instructional Design and Technology Validation}

The validation process in instructional design of the prototype was carried out through by semistructured interviews with the experts. The comments and suggestions were divided into 12 themes as shown below:

\begin{tabular}{|c|c|c|}
\hline Item & Comments & Suggestions \\
\hline User Interface & $\begin{array}{l}\text { 1. The game is very simple and } \\
\text { appropriate to elementary } \\
\text { learners. } \\
\text { 2. Less exciting to young } \\
\text { university learner. } \\
\text { 3. The presentation of main menu } \\
\text { is less attractive. } \\
\text { 4. It should have developer } \\
\text { interface before going to main } \\
\text { menu. }\end{array}$ & $\begin{array}{l}\text { 1. Add more instructional icons. } \\
2 \text {. Add colour or interactive } \\
\text { background instead of use white } \\
\text { background. } \\
\text { 3. Add introduction of the game. } \\
4 \text {. Put the vocabulary in the } \\
\text { interactive shape to increase the } \\
\text { excitement. } \\
5 \text {. Use different icons for the menu } \\
\text { boxes to differentiate the level. }\end{array}$ \\
\hline Game Navigation & $\begin{array}{l}\text { 1. The game navigation is clear. } \\
\text { 2. The initial step to take is not } \\
\text { clear to beginner students. } \\
\text { 3. Arabic instruction may not be } \\
\text { understood by beginner students. }\end{array}$ & $\begin{array}{l}\text { 1. The instruction should be in } \\
\text { English. } \\
\text { 2. Add interactive icons at } \\
\text { instructions. } \\
\text { 3. Add column "how to play". }\end{array}$ \\
\hline Game Template & $\begin{array}{l}\text { 1. The game template is easy and } \\
\text { appropriate to beginner students. }\end{array}$ & $\begin{array}{l}\text { 1. Revise the technical parts for } \\
\text { rearrange vocabulary game and } \\
\text { construct sentences game. } \\
\text { 2. Add button reset for every game. }\end{array}$ \\
\hline Game ease of play & $\begin{array}{l}\text { 1. Smooth and ease to play. } \\
\text { 2. To drag the answer only work if } \\
\text { clicked on the Arabic script only. }\end{array}$ & 1. Revise the technical parts. \\
\hline Game difficulty & $\begin{array}{l}\text { 1. The game level is not clear. } \\
\text { 2. The arrangement game } \\
\text { difficulty is good. }\end{array}$ & $\begin{array}{l}\text { 1. Put the name of each game } \\
\text { clearly. } \\
\text { 2. Separate the game according to } \\
\text { the level. }\end{array}$ \\
\hline $\begin{array}{l}\text { Concerning design and } \\
\text { development } \\
\text { principles }\end{array}$ & $\begin{array}{l}\text { 1. The game follows game } \\
\text { principles by Bobers ( } 2010) \text {. } \\
\text { 2. The elements of fantasy was } \\
\text { not well built into the system. } \\
\text { 3. Challenge was clearly through } \\
\text { the difficult level of the content. }\end{array}$ & $\begin{array}{l}\text { 1. Add interactive total score board. } \\
\text { 2. Timing can be built into to drive } \\
\text { challenge element. }\end{array}$ \\
\hline
\end{tabular}


INTERNATIONAL JOURNAL OF ACADEMIC RESEARCH IN PROGRESSIVE EDUCATION AND DEVELOPMENT

Vol. 8, No. 3, 2019, E-ISSN: $2226-6348$ @ 2019 HRMARS

\begin{tabular}{|c|c|c|}
\hline Game responsiveness & $\begin{array}{l}\text { 1. No issue except for some } \\
\text { instance when the response was } \\
\text { a bit slower. }\end{array}$ & 1. Revise the technical parts. \\
\hline $\begin{array}{l}\text { Distraction of sound } \\
\text { effect }\end{array}$ & $\begin{array}{l}\text { 1. No distraction. } \\
\text { 2. A good sound effect from } \\
\text { Arabic native speaker. } \\
\text { 3. The quality of the audio can be } \\
\text { improved in clarity and be more } \\
\text { natural in daily conversation. }\end{array}$ & $\begin{array}{l}\text { 1. Add sound effect for the correct } \\
\text { and wrong answer. }\end{array}$ \\
\hline Quality graphic used & $\begin{array}{l}\text { 1. The quality of the graphic used } \\
\text { can be improved. }\end{array}$ & 1. Add more interesting icons. \\
\hline $\begin{array}{l}\text { Distraction of text } \\
\text { used }\end{array}$ & $\begin{array}{l}\text { 1. No distraction. } \\
\text { 2. Simple and crisp interface. }\end{array}$ & 1. Put the text centre. \\
\hline $\begin{array}{l}\text { Motivation level in } \\
\text { learning }\end{array}$ & $\begin{array}{l}\text { 1. Appreciate the score feature } \\
\text { very much for extrinsic } \\
\text { motivation. } \\
\text { 2. The game is acceptable for } \\
\text { those who wants to do a mission. }\end{array}$ & 1. Add interactive total score board. \\
\hline $\begin{array}{l}\text { Overall view of } \\
\text { prototype }\end{array}$ & $\begin{array}{l}\text { 1. It is a promising game. } \\
\text { Congrats! } \\
2 . \text { Good and workable only that } \\
\text { some elements can be improved } \\
\text { further. } \\
\text { 3. Well done! A few additional } \\
\text { game elements can be built in to } \\
\text { enhance engagement. } \\
\text { 4. Good and need to improve in } \\
\text { terms of multimedia elements. } \\
\text { 5. Excellent. A few things need to } \\
\text { be improve to ensure students } \\
\text { motivation, achievement and } \\
\text { interest towards digital game } \\
\text { increase. }\end{array}$ & 1. Improve all the mentioned. \\
\hline
\end{tabular}

Table 0-2 Experts' Comments and Suggestions in Instructional Design

\section{Discussions}

This study encompasses the validation process of e-Mufradat; an educational digital game platform for learning Arabic vocabulary. This process is important to determine that the application is of good quality before being adopted in the classroom. This process allows the researchers to identify and rectify errors. In this regard, it was observed that while there are many digital games available in market place, it was found that some of these apps are not developed based on students' need (Nurkhamimi \& Muhammad Sabri, 2015) and did not go through the expert validation process. Furthermore, some of these apps contain content and technical errors and are not suitable to be used by students as they do not fit the students' learning environment, culture, as well as teachers' and students' readiness.

There are several factors emphasized by the experts, such as the use of multimedia element to attract students' interest and motivation and to sustain their engagement throughout 
the teaching and learning process. Studies have reported that presenting the information in the form interactive multimedia could help students store the information longer compared to using text or oral delivery, for instance, the use of appropriate and clear graphics to introduce new vocabulary (Kalyuga et. al, 2013; Agca et. al, 2013; Ramlan, 2016). The experts also agreed that using sound or video clips of a native Arabic speaker could help improve student's listening skill and their pronunciation. Furthermore, the experts also commented about the layout and mentioned that while the texts given are clear and legible, they need to be put at the centre to make the app look more structured.

They also emphasised on the use of instructional icons in the digital game. The drag and drop feature of e-Mufradat should be accompanied with some instructional icons. Since the eMufradat is designed for beginners, adding instructional icons will help them to navigate the eMufradat and make it easier for them to explore the game. The use of suitable and appropriate instructional icons could enhance students' engagement towards the digital game.

In addition, the experts agreed that the e-Mufradat follows the game principles by Bober (2010) but it still needs several improvements, specifically the element of challenges and fantasy. Different challenges and level of difficulties should be added to the e-Mufradat application. In addition, the difficulty level in the game is well structured, however, it could be difficult for beginners to understand the goal of each game. Therefore, it is advised to restructure all the games and separate them according to level. In addition, the element of fantasy should be embedded into the e-Mufradat by providing avatars for players, and the narrative of the game. From here, it can be concluded that the rest of the principles are successfully embedded into the e-Mufradat.

In all, the initial prototype is considered as good, but several crucial improvements need to be made to enhance the quality of the game and align it with the principles to ensure all goals are achieved. This study also discussed the appropriate implementation of the multimedia learning and digital game-based learning theory into the e-Mufradat application. Since this study involves an educational game protocol, it should be tested and re-tested to improve it reliability before it can be implemented to actual participants and publishing into the market place.

\section{Conclusion}

An effective digital game must be well structured and the contents should be appropriate and relevant to the students' needs and the learning contexts. In this regard, this paper presented a validation process of e-Mufradat which is digital game application for learning Arabic. The review involved semi-structured interview sessions with experts and their comments and suggestions were considered to enhance the app.

The major finding of this study is the multimedia elements play an important role in engaging the students using e-Mufradat in learning process. The students are more keen to learn Arabic language as the e-Mufradat equipped with various multimedia elements such as fancy texts, clear audio clips, interesting pictures and animation. Furthermore, e-Mufradat is suitable for elementary learners as the game content, challenges, difficulty level are well structured based on student's need.

This study has several theoretical contributions. It validates several theories in regards to the design and development of e-Mufradat. It is advocated that multimedia learning and digital 
game-based learning should be blended equally to produce a high quality educational game. Furthermore, the e-Mufradat app will contribute to the practice of teaching and learning Arabic for non-native students. The e-Mufradat application offers a fun and engaging learning experience and provides with them a new learning environment. It also helps develops soft skills, higher order thinking skills and allows them to learn to practice self-learning as the application can be accessed using their mobile devices.

\section{Recommendation}

As the e-Mufradat has been developed and going through several improvements, for further investigation, the e-Mufradat could be assessed quantitatively via a quasi-experiment to evaluate its effectiveness in the learning Arabic language among non-native speakers. Moreover, future research should employ a survey on the usability of e-Mufradat by involving experts, teachers, and students. Besides, this study also would like to recommend to conduct a survey study on user acceptance of e-Mufradat based on technology adoption model.

\section{References}

Razif, A. Z., \& Zaki, M. A. R. (2017). Arabic Language Vocabulary Size and its Realtion with Speaking Skills. Juranl Sultan Alauddin Sulaiman Shah, 4(1), 220-228.

Abu, M. R. (2001). The Impact of Using Computerized Games in the Sixth Grade Students in Acquiring the Four Arithmetic Algorithms. Studies of Educational Sciences, 164-176.

Agca, R. K., \& Ozdemir, S. (2013). Foreign Language Vocabulary Learning With Mobile Technologies. Procedia - Social and Behavioral Sciences, 781-785.

Baumann, J. F., \& Kame'enui, E. J. (2003). Vocabulary Instruction: Research to Practice. New York: Guilford Press.

Bober, M. (2010). Games Based Experiences for Learning. Bristol: Futurelab.

Creswell, J. W. \& Creswell, J. D. (2018). Research Design: Qualitative, Quantitative, and Mixed Methods Approaches. Carlifonia: Sage.

$\mathrm{Gu}, \mathrm{Y}$. (2010). Learning Strategies for Vocabulary Development. Reflection on English Language Teaching, 9(2), 105-118.

Hamizul, M. \& Rahimi, N. M. (2015). Design and Development of Arabic Online Games: A Conceptual Paper. Procedia Social and Behavioral Sciences, 174, 1428-1433.

Hussain, S. Y. S., Tan, W. H., \& Idris, M. Z. (2014). Digital Game-based Learning for Remedial Mathematics Students: A new Teaching and Learning Approach in Malaysia. International Journal of Multimedia Ubiquitous Engineering, 9(11), 325-338.

Hwang, G. J., Wu, P. H., \& Chen, C. C. (2012). An Online Game Approach For Improving Students' Learning Performance In Web-Based Problem-Solving Activities. Computers \& Education, 1246-1256.

Iverson, K. M. (2005). E-learning Games, Interactive Learning Strategies for Digital Delivery. New Jersey: USA: Pearson Education.

Janudin, S. (2017). Learning Arabic Language via Interactive Mobile Application. International Carnival on e-Learning (pp. 361-363). Nilai: Universiti Sains Islam Malaysia.

Juul, J. (2003). The Game, The Player, The World: Looking for a Heart of Gameness. Digital Games Research Conference (p. 121). Utrecht, Holland: Utrecht University. 
INTERNATIONAL JOURNAL OF ACADEMIC RESEARCH IN PROGRESSIVE EDUCATION AND DEVELOPMENT

Vol. 8, No. 3, 2019, E-ISSN: 2226-6348 @ 2019 HRMARS

Kalyuga, M., Mantai, L., \& Marrone, M. (2013). Efficient Vocabulary Learning Through Online Activities. Procedia - Social and Behavioral Sciences, 35-38.

Lee, J. \& Hammer, J. (2011). Gamification in Education: What, how, why bother? Academic Exchange Quartely, 15(2), 146.

Mayer, R. E. (2001). Multimedia Learning. Cambridge University.

Nacera, A. (2010). Language Learning Strategies and The Vocabulary Size. Procedia Social and Behavioral Sciences.

Nathesan, S. (2011). Leksikon: Kosa Kata Bahasa (Vol. 11). Kuala Lumpur: Dewan Bahasa dan Pustaka.

Nurkhamimi, Z. \& Sabri, M. S. (2015). Theories And Design Principles of Multimedia Courseware For Teaching Arabic Vocabulary: An Analytical And Evaluative Study. International Journal of Technical Research and Applications, 29-32.

Oxford, R. L. (1990). Language Learning Strategies: What Every Teacher Should Know. Boston: Heinle \& Heinle.

Paiva, A. C. R., Flores, N. H., Barbosa, A. G., \& Ribeiro, T. P. B. (2016). iLearnTest - Framework For Educational Games. Procedia - Social And Behavioral Sciences, 443-448.

Papastergiou, M. (2009). Digital Game-Based Learning in High School Computer Science Education: Impact on Educational Effectiveness and Student Motivation. Computers \& Education, 1-12.

Prensky, M. (2001). Digital Game-Based Learning. USA: Paragon House.

Ramlan, N. A. (2016). Vocabulary on the Move: The Use of Mobile Applications in Learning Vocabulary. National Conference on Research on Language Education 2016 (pp. 200206). Melaka: Universiti Teknologi MARA.

Richey, R. C., \& Klein, J. D. (2007). Design and Development Research. New Jersey: USA: Lawrence Erlbaum Associates.

Rosni, S. (2009). Isu Pembelajaran Bahasa Arab di Malaysia. Nilai: Universiti Sains Islam Malaysia.

Rosni, S. (December, 2017). Pembelajaran Bahasa Arab Perlukan Perubahan. Universiti Sains Islam Malaysia. Nilai: USIM News. Retrieved from https://www.usim.edu.my/news/inour-words/pembelajaran-bahasa-arab-perlu-perubahan/

Salen, K. \& Zimmerman, E. (2004). Rule of Play: Game Design Fundemantals. Cambridge: MIT Press.

Samir, N., \& Randa, E. S. (2012). Educational Games: Do They Make A Difference? Procedia Social and Behavioral Sciences, 48-51.

Schmitt, N. (2000). Vocabulary in Language Teaching. TESOL Quaeterly, 36, 235. doi:http://doi.org/10.2307/3588334

Sung, H. Y. \& Hwang, G. J. (2013). A Collaborative Game-Based learning Approach To Improving Students' Learning Performance in Science Coueces. Computers \& education, 43-51.

Tight, D. G. (2010). Perceptual Learning Style Matching and L2 Vocabulary Acquisition. Language Learning, 60, 792-833.

Yien, J. M., Hung, C. M., Hwang, G. J., \& Lin, Y. C. (2011). A Game-Based Learning Approach To Improving Students' Learning Achievements In A Nutrition Course. The Turkish Online Journal of Educational Technology, 10(2). 


\section{INTERNATIONAL JOURNAL OF ACADEMIC RESEARCH IN PROGRESSIVE EDUCATION AND}

DEVELOPMENT

Vol. 8, No. 3, 2019, E-ISSN: 2226-6348 @ 2019 HRMARS

Zaini, A. R., \& Rahman, A. M. Z. (2017). Saiz Kosa Kata Bahasa Arab dan Hubungannya dengan Kemahiran Bertutur. Jurnal Sultan Alauddin Sulaiman Shah, 4(1), 220-228. 